\title{
The Effect of Farmer's Behavior on Land Degradation Level in Upper Sumber Brantas River Basin
}

\author{
$1^{\text {st }}$ Aida Kurniawati \\ Department of Geography, Faculty of \\ Social Sciences and Law \\ Universitas Negeri Surabaya \\ Surabaya, Indonesia \\ aidakurniawati@unesa.ac.id
}

\author{
$2^{\text {nd }}$ Nugroho Hari Purnomo \\ Department of Geography, Faculty of \\ Social Sciences and Law \\ Universitas Negeri Surabaya \\ Surabaya, Indonesia \\ nugrohohari@unesa.ac.id
}

\author{
$3^{\text {rd }}$ Eko Budiyanto \\ Department of Geography, Faculty of \\ Social Sciences and Law \\ Universitas Negeri Surabaya \\ Surabaya, Indonesia \\ ekobudiyanto@unesa.ac.id
}

\begin{abstract}
The purpose of this study was to determine the effect of farmer behavior on the level of land degradation. The data needed are field data, farmer interviews, and spatial data. The Sumber Brantas watershed problem is caused by physical land factors, the economy of the community, the existence of social factors that trigger conflicts at the community and government levels. The difference in perspective on natural resource management efforts in this watershed if left unchecked will exacerbate the damage to natural resources in this region. Therefore, efforts need to be shared by all stakeholders related to the condition of the Sumber Brantas watershed and what is happening in this sub-watershed. The data needed in this study are field data and spatial data. Then it will be processed using GIS (Geographic Information System). To find out the relationship between farmer behavior with land degradation level then calculated with Pearson Product Moment.
\end{abstract}

Keywords — erosion, land degradation

\section{INTRODUCTION}

Land conversion causes land degradation [1]. The increase in human population and changes in human lifestyles have caused pressure on the land because resources are over-exploited. Forest Watch Indonesia (2011), reported that forests in Indonesia experienced deforestation of 15 million ha from 2000 to 2009. In 2000 the forest area in Indonesia was 103 million ha and decreased to 88 million ha in 2009. [2] stated that the impact of changes in forest land results in changes in the hydrological balance in a catchment area, and changes in the biophysical conditions of the land in the form of changes in vegetation composition and changes in microclimate [3]. This condition is exacerbated by climate change [4], [5].

The increase in human population and changes in human lifestyles have caused pressure on the land because resources are over-exploited. Forest Watch Indonesia (2011), reported that forests in Indonesia experienced deforestation of 15 million ha from 2000 to 2009. In 2000 the forest area in Indonesia was 103 million ha and decreased to 88 million ha in 2009. [2] stated that the impact of changes in forest land results in changes in the hydrological balance in a catchment area, and changes in the biophysical conditions of the land in the form of changes in vegetation composition and changes in microclimate [3]. This condition is exacerbated by climate change [4], [5].

Human population and lifestyle cause pressure on the land so that land functions change. Transfer of land function causes erosion [1]. In addition to these factors, physical factors of land also cause erosion, especially in soil types [6]. This type of soil is a physical factor of land that must be considered because it affects the level of vulnerability to erosion. For example, andosols are generally found in the highlands. The nature of this soil type is high permeability, so the ability to hold large water [7]. Crumb structure and sandy clay texture, so that this type of soil is easily released. Another triggering factor for climate change that is taking place at this time has an impact on the intensity and frequency of rain so that it triggers erosion and land degradation [8], [9]. Especially on upland areas that are widely cultivated by vegetable crops [10].

Land in the highlands is generally carried out by intensive farming because vegetables have a relatively short planting period so that the land is often processed. Vegetable planting period ranges from 2-3 months. Besides that the highlands generally have quite steep slopes, this will increase the occurrence of erosion [11]. Uncontrolled erosion will cause land degradation and even critical land. In addition to the factors mentioned previously there are other factors that are very important to be studied, namely the behavior of the farming community. Farmers are subjects that are directly related to the land because farmers have a large influence on the land. Farmers are able to change barren land into fertile, as well as fertile land that can turn into the land that is damaged by farmers. The skills and experience of farmers during farming are local content owned by each region. Because of the importance of knowing the behavior of farmers with the level of land degradation.

Erosion is a process of destruction and transfer of land to another place. According to [12], the process of erosion can be caused by the presence of corrosion forces in the form of water flow, groundwater, waves and currents, 
winds, and glaciers. However, Sarief (2001) asserts that in humid tropical climates such as in Indonesia with rainfall ratios exceeding $1500 \mathrm{~mm}$ per year, water is the main cause of erosion.

\section{RESEARCH METHODS}

\section{A. Location and time of research}

The location of this study is geographically located at the position of $115^{\circ} 17^{\prime} 0$ 'to $118^{\circ} 19^{\prime} 0^{\prime}$ 'East Longitude (BT) and $7^{\circ} 55^{\prime} 30^{\prime}$ 'to $7^{\circ} \quad 57^{\prime} 30^{\prime}$ 'South Latitude (LS). Administratively, the Upper Brantas watershed covers 3 sub-districts, namely Junrejo District, Bumiaji Subdistrict and Batu District with boundaries: (1) east of Karangploso District; (2) west of Pujon District; (3) in the north bordering Mojokerto Regency, Pasuruan Regency, Singosari District and Prigen District; and (4) south of Wagir District and Dau District.

\section{TABLE I. LOCATION OF THE SAMPLE POINT RESEARCH}

\begin{tabular}{|c|l|c|c|}
\hline $\begin{array}{c}\text { Statio } \\
\mathbf{n} \\
\text { locati } \\
\text { on } \\
\text { code }\end{array}$ & $\begin{array}{c}\text { Location of } \\
\text { weather } \\
\text { quality control } \\
\text { station }\end{array}$ & $\begin{array}{c}\text { Coordinat } \\
\mathbf{e} \mathbf{x}(\mathbf{m})\end{array}$ & $\begin{array}{c}\text { Coordinat } \\
\mathbf{e} \mathbf{y}(\mathbf{m})\end{array}$ \\
\hline 1 & forest & 691401 & 9201132 \\
\hline 2 & $\begin{array}{l}\text { Cabbage moor } \\
1\end{array}$ & 687147 & 9196056 \\
\hline 3 & $\begin{array}{l}\text { Cabbage moor } \\
2\end{array}$ & 689498 & 9188463 \\
\hline 4 & $\begin{array}{l}\text { Cabbage moor } \\
3\end{array}$ & 696983 & 9193990 \\
\hline 5 & Apple orchard & 692390 & 9196946 \\
\hline
\end{tabular}

The erosion monitoring location is presented in Figure 1. At this location, erosion samples were taken with 3 points for the type of cabbage. Cabbage is the most planted crop at that time, so it becomes a sample for erosion sampling. Cabbage plants are carried out with 3 repetitions. And done with 3 treatments.

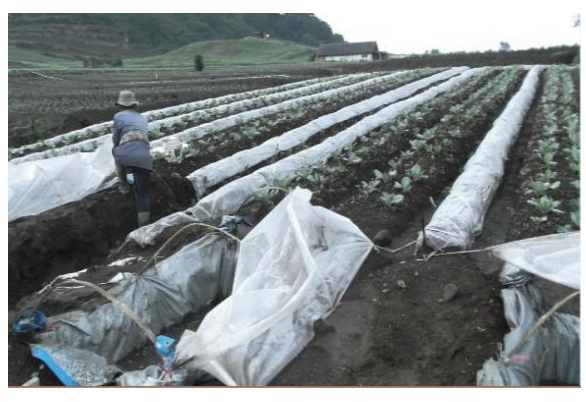

Figure 1. sampling erosion

Erosion sampling is carried out using a plot scale. Sample erosion using 5 types of land use on the same type of soil, slope, and landform. The type of land use is; apple orchard with 3 replicates, 3 replication forest, 3 types of conservation cabbage and 3 repetitions. All erosion data is taken every time there is rain. Erosion data collection is done by using

\section{Tools and Material}

The tools and materials needed are:

a. The main data in this study are the results of field surveys, measurements, and observations at the study site

b. Landsat Image OLI Data 8 months May 2016 recording to get land use data. The acquisition of image data is done by accessing the NASA portal at http://earthexplorer.usgs.gov. Image data with scene Id LC81180652015167LGN00 specification Path 118, Raw 65

c. Coordinate and elevation data, obtained from GPS measurements in the field

d. Soil samples from the field to find out the texture, structure in permeability and organic matter

e. Map of Rupa Bumi Indonesia Scale 1: 25.000 Bumiaji issued by National Coordinating Survey and Mapping Agency, Bogor 2015.

f. Rainfall data issued by the East Java watershed management body in 2007-2016 were recorded from 7 stations.

g. Ombrometer to measure rain in the field.

This research is a qualitative descriptive study. Research conducted 1 year, ie in August 2015 to August 2016 in Sub Brantas of East Java. This study was conducted in 3 stages. Stage 1 is preparing the data that is the image of satellite OLI obtained by downloading to USGS via earthexplorer.gov. Then performed image rectification that is geometry correction and radiometric correction. Image interpretation is done to obtain physical information of land, including flow density, land cover, and slope. Image processing is done with Quantum Geographic information System version 2.16. Stage 2 measures actual erosion, yield and magnitude of erosion as shown in Table 1.1. Stage 3 interview on farmers. The population in this study were all farmers who at the time were planting cabbage. Cabbage researchers select because when the research took place over $50 \%$ of farmers are planting cabbage. Interviews were conducted with a questionnaire guide. Questions are fertilization, use of pesticides, irrigation, use of mounds, planting rotation in a year, farmers' knowledge of erosion, and the need for sustainable agriculture.

Map 1.1 Where the observation took place. The given color of the map informed of the land degradation level. Determination of land degradation level based on erosion level which measures on level 2 research. Each land degradation level will be correlated with the behavior of the local farmers.

The simple correlation formula is :

$$
\mathrm{r}=\frac{\mathrm{n} \Sigma \mathrm{xy}-(\Sigma \mathrm{x})(\Sigma \mathrm{y})}{\sqrt{ }\left\{\mathrm{n} \Sigma \mathrm{x}^{2}-(\Sigma \mathrm{x})^{2}\right\}\left\{\mathrm{n} \Sigma \mathrm{y}^{2}-(\Sigma \mathrm{y})^{2}\right\}}
$$

Where

$\mathrm{n}=$ number of pairs of data $\mathrm{x}$ and $\mathrm{y}$

$\Sigma \mathrm{x}=$ total amount of variable $\mathrm{x}$

$\Sigma y=$ total amount of variable $\mathrm{y}$ 
$\Sigma \mathrm{x}^{2}=$ square of total number of variable $\mathrm{x}$

$\Sigma \mathrm{x})^{2}=$ square of the total number of variable $\mathrm{y}$

$\Sigma x y=$ Result of Multiplication of Total Number of Variables $\mathrm{X}$ and Variable Y

\section{Determination of unit analysis}

The smallest unit of analysis of this study consists of land, slope, type of soil and land shape, which are overlayed by one another.

Unit analysis observation

Unit analysis is carried out by calculating an overlapping the composition of land units, erosion and behavior of farmer communities so that the relationship of each unit of analysis can be identified.

\section{III.RESULT AND DISCUSSION}

\section{Erosion level}

The level of erosion that occurs in the upper brantas watershed is as shown in Figure 2. As follows:

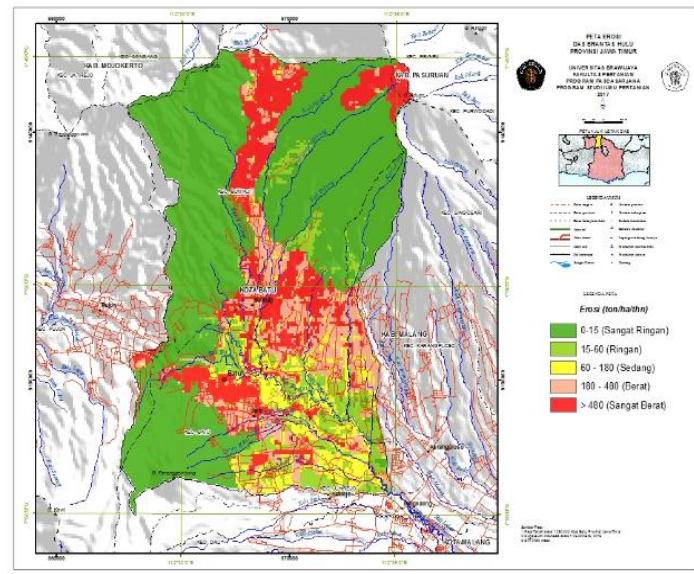

Figure 2. Actual erosion value in the Upper Brantas River basin

Figure 2 shows that the greatest erosion rate occurs in the upper to middle slopes. This is because the area is dominated by dry land with vegetable crops. Vegetables are plants that are widely planted in the area, especially the cabbage, carrots, mustard greens, and potatoes. In addition, flower plants are also cultivated in these areas.

The value of erosion occurring in the study area is very large between 160 - 480 tons/ ha/yr. This large erosion is because the slopes in the study area are very steep, with andosol-dominated soil types that have high release rates, so erosion is very vulnerable in the study area.

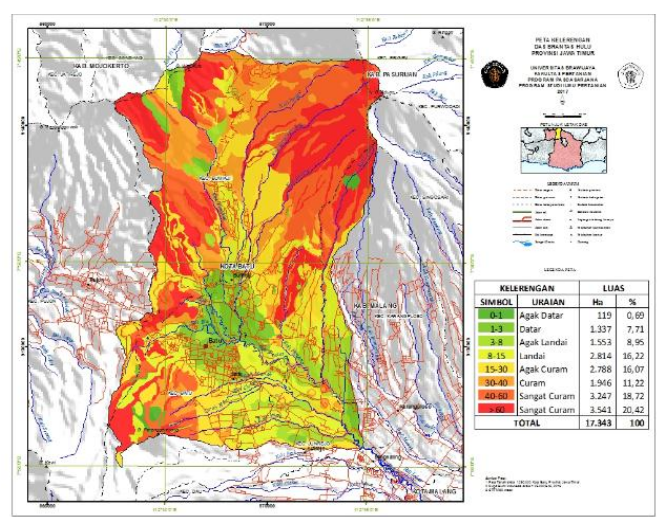

Figure 3. The slope of the study area

Slopes have a large role in holding back the rate of water. The steeper of the slope, the faster the flow will be generated. Erosion. There is a relationship between the angle of the slope with the magnitude of the erosion is as shown in Figure 4. The steeper the slope the greater the resulting erosion.

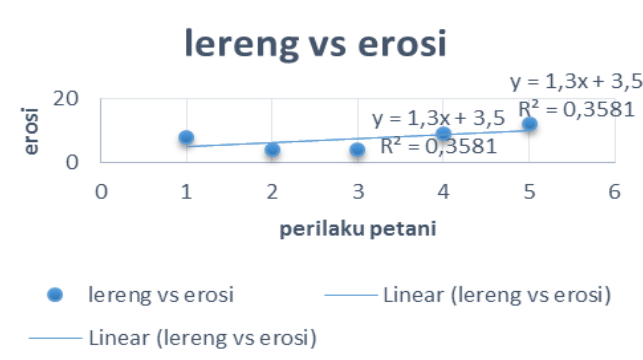

Gambar 4. The relation between slope and erosion

\section{B. The relationship between farmer behavior and the level of land degradation.}

Farmers, especially farmers, who are in mountainous areas generally plant horticultural crops that play a major role in land damage [8], [9]. Agriculture on this land generally does not apply the rules of land conservation, because the plant requires a wet environment but not waterlogged, so many farmers in order to pursue the profits of sacrificing land so that the erosion is inevitable (Suripin, 2009). Erosion has become very intensive due to changes in seasons in the last few years. Erosion is one of the causes.

Land degradation 1. Land degradation 1 is a watershed sub-basin with steep $50 \%$ slope, $60 \%$ of land use is shrubs. In this area, farmers cultivate their land $100 \%$ by hoeing. Fertilization is done on average 2-4 times one-time planting. Farmers who are on the physical ground (degradation category 1) have the poorest knowledge and behavior that score 48 means in terms of good knowledge but the behavior is not good because for the land with sloping conditions the ridges will be made in the direction of the slope. The reason is if the guludan not in the direction of the slope, the farmer will suffer losses because of the plant rot. The decay of plants is caused by the plants submerged in water, so the making of the bunds with the slope direction model is correct.

As for the farmers on the degraded watershed, 2 is the knowledge and behavior of farmers with a physical score 
of 64. From the calculation of farmers' knowledge is a score of 32 and the behavior score of 43 . From this score can be translated into areas with degradation 2 physical conditions are not too extreme while the population has the knowledge and moderate behavior. In this degraded basin 2, these bunds have varied not dominated bunds in the direction of the slopes only but the combination with the bunds on the porch of the bench

Degradation 3 is the lowest degradation rate. Judging from the physical factors this degradation has characteristics, less flow density, the slope is not too extreme and the land cover varies. From the results of calculations in this study will be presented data related to the behavior of farmers. From the results of interviews in the field, farmers' knowledge of erosion is very good. Farmers know the symptoms of erosion in the field from water turbidity, slope, rainfall.

Meanwhile, the aspect of land loss is not too much concerned or even ignored by the community. The community does not feel the loss/loss of erosion, because there are no things that are directly felt when erosion occurs. Actually, through a trend analysis (trend analysis) that was made by the community when the survey meeting revealed that there had indeed been a gradual change in the land/land in the watershed due to erosion. Negative changes can be identified through a number of indicators mentioned by the community such as (a) increasing fertilizer requirements, (b) continuously decreasing production (eg apples), (c) the existence of plants that used to grow well but not now (for example potato). Erosion only occurs on slopes that are not overlaid. The amount of erosion is not affected by the type of annual crops planted, but by the presence or absence of a good terrace. Erosion can be reduced by making the terraces.

\section{CONCLUSIONS}

Meanwhile, the aspect of land loss is not too much concerned or even ignored by the community. The community does not feel the loss/loss of erosion, because there are no things that are directly felt when erosion occurs. Actually, through a trend analysis (trend analysis) that was made by the community when the survey meeting revealed that there had indeed been a gradual change in the land/land in the watershed due to erosion. Negative changes can be identified through a number of indicators mentioned by the community such as (a) increasing fertilizer requirements, (b) continuously decreasing production (eg apples), (c) the existence of plants that used to grow well but not now (for example potato). Erosion only occurs on slopes that are not overlaid. The magnitude of erosion is not affected by the type of seasonal crops planted, but by the presence or absence of a good terrace. Erosion can be reduced by making the terraces.

\section{ACKNOWLEDGMENT}

This research can be completed with the assistance of FISH UNESA through faculty policy funds in 2017.

\section{REFERENCES}

pp. 234-246, 2013

M. M. Alkharabsheh, T. K. Alexandridis, G. Bilas, N. Misopolinos, and N. Silleos, "Impact of Land Cover Change on Soil Erosion Hazard in Northern Jordan Using Remote Sensing and GIS," Procedia Environ. Sci., vol. 19, pp. 912-921, 2013.

[3] J. Beullens, D. Van de Velde, and J. Nyssen, "Impact of slope aspect on hydrological rainfall and on the magnitude of rill erosion in Belgium and northern France," Catena, vol. 114, pp. 129-139, 2014.

[4] Q. J. Liu, Z. H. Shi, X. X. Yu, and H. Y. Zhang, "Influence of microtopography, ridge geometry and rainfall intensity on soil erosion induced by contouring failure," Soil Tillage Res., vol. 136, pp. 1-8, 2014.

[5] Y. ming Lin et al., "The succession characteristics of soil erosion during different vegetation succession stages in the dry-hot river valley of jinsha river, upper reaches of yangtze river," Ecol. Eng., vol. 62, pp. 13-26, 2014.

[6] M. M. Ebeid, R. Lal, G. F. Hall, and E. Miller, "Erosion effects on soil properties and soybean yield of a Miamian soil in Western Ohio in a season with below normal rainfall," Soil Technol., vol. 8, no. 2, pp. 97-108, 1995.

[7] M. Heckmann, "Farmers, smelters, and caravans: Two thousand years of land use and soil erosion in North Pare, NE Tanzania," Catena, vol. 113, pp. 187-201, 2014.

[8] S. K. Chen, C. W. Liu, and Y. R. Chen, "Assessing soil erosion in a terraced paddy field using experimental measurements and universal soil loss equation," Catena, vol. 95, pp. 131-141, 2012.

[9] R. Ciampalini, P. Billi, G. Ferrari, L. Borselli, and S. Follain, "Soil erosion induced by land use changes as determined by plough marks and field evidence in the Aksum area (Ethiopia)," Agric. Ecosyst. Environ., vol. 146, no. 1, pp. 197-208, 2012.

[10] N. Smith and A. Leiserowitz, "American evangelicals and global warming," Glob. Environ. Chang., vol. 23, no. 5, pp. 1009-1017, 2013.

[11] J. Hooke and P. Sandercock, "Use of vegetation to combat desertification and land degradation: Recommendations and guidelines for spatial strategies in Mediterranean lands," Landsc. Urban Plan., vol. 107, no. 4, pp. 389-400, 2012.

[12] M. Lorenz, C. Fürst, and E. Thiel, "A methodological approach for deriving regional crop rotations as the basis for the assessment of the impact of agricultural strategies using soil erosion as example," J. Environ. Manage., vol. 127, pp. S37S47, 2013. 